Pakistan Journal of Education

Vol.37, No.1, 2020, 75-94

\title{
Impact of Different Levels of Schooling on Development of Students' Social Attitudes
}

\author{
Shamas Suleman Arshad ${ }^{*}$ \\ Sher Zaman ${ }^{* *}$
}

\begin{abstract}
One of the expectations of society from schooling is to develop students' pro social behavior shaving roots in their knowledge, beliefs and social attitudes. But the assessment procedures related to students' social dispositions and attitudes are generally missing, therefore probably least addressed in the instructional system. For the purpose a systematic investigation was conducted as whether current schooling meaningfully develops students' social attitudes, a prerequisite for the desired prosocial behaviors. Hence, the study explored the impact of schooling empirically, on the social attitudes during schooling from elementary to secondary levels. A sample from 16 schools of 480 students was taken, for which a 'social attitude scale', having four subscales, i.e., a) concern for others' welfare, b) respect for laws, c) respect for others' property and d) sensitivity to social issues, was developed to collect data. Analysis results of the collected data, revealed that the overall impact of different levels of schooling for upward positive increase in students' social attitude was negligible, although elementary schooling contributed more as compared to secondary level. Similarly public sector schooling across three stages had more impact on students' social attitudes as compared to the private sector schools.
\end{abstract}

Keywords: schools, social attitudes, prosocial and antisocial behaviors, public and private schooling

\footnotetext{
* Principal author: PhD scholar at University of Gujrat \& Lecturer Education, Govt. Abdul Haq Islamia Degree College Jalal Pur Jattan, Gujrat, Pakistan.

** Assistant Professor Education, Department of Education UOG, Pakistan,

Email: smzaman@uog.edu.pk
} 


\section{Introduction}

Children's social interactions extend from home to preschool and then to formal schooling. Schooling being a formal program is designed to foster cognitive and social development of the young children. Students' entry into schooling brings an expansion in their social world view where their teachers and peers may have a potential impact for them in their multifaceted development, which Slavin (2006) refers to the way people grow, adapt and change over their lifetimes in the areas of physical, personality, socio emotional, cognitive and language developments. Simultaneously the parents' influence on children's various developments decreases as it were during their early age at home and the other factors like school curriculum, peers, society and teachers play their predetermined part in students' multifaceted development.

Among the children's different development domains, the emphasis of the current study is on the commonly missing one, i.e., social development during 10-16years.Prior to the age stage, children would have completed their early education that prepares them to take initiatives and later on to be able to resolve their personality social crises(Erickson, 1963). Students' education at this stage involves their growth of independent action, cooperation with others, and acceptable social behaviors, with a concern for fair play (McHale, Dariotis, \& Kauh, 2003).By the time, children in elementary schools would have developed skills for more complex thoughts, actions and social influence (Slavin, 2006). After the elementary stage, i.e., during adolescence, Erikson believed that the individual's rapidly change physiology, coupled with pressures to make decisions about future education and career, creates the need to question and redefine the psychosocial identity established during the children earlier life stages (Erickson, 1980).

The stated human growth and multifaceted development is indispensable, but a question arises about the role of the influencing factors from family to schooling. The ongoing instructional practices probably focus on imparting knowledge, somehow cognitive development, but might not contribute effectively to students' socioemotional development. Schwille and Amadeo (2002) were of the belief that school education is elusive to tackle great social issues of democracy, national identity, and social cohesion areas that are so important to societies of the day. However, Mangal (2007) emphasized that an individual's social development which related to living with others or to live together, was crucial for the learners for their good citizenship. 
Moreover, Can and Inelmen (2011) put forth that there is social demand from the education system to lay more emphasis on character building of students and society. They held teachers, in general, responsible for the purpose of developing students' prosocial behaviors, because to them school is a place for socializing individuals. Similarly, Iram and Ambreen (2017) found association in students' positive social development with their acceptance of the school environment including teachers and other curricular activities. It implies the poor school settings which lack prosocial cultures, consequently affect students' academic performances and behaviors undesirably (Blum, Libbey, Bishop, \& Bishop, 2004).

Hence, it is construed that appropriate social behaviors and prosocial skills such as helping and sharing among students need to be systematically developed and ignoring antisocial behavior such as fighting and verbal aggression on the part of good students should be reinforced in schooling. The research findings of Olweus (1994) and White and Kistner (1992) support two major interventions i.e. modeling and coaching during schooling for students' development. Children who observe role models learn positive social skills and show significant improvement in their own prosocial behaviors. Further to them, coaching is a strategy that involves a sequence of steps including demonstrating positive social skills, explaining why these skills are important, providing opportunities for practice, and giving follow-up feedback. The effectiveness of such interventions is more likely dependent on the involvement of the child's peers and classroom teachers.

A young child's social life evolves in predictable ways through their social network including intimate relationships with parents, other family members, and nonrelated peers and teachers. In the beginning first three stages, the interactions are primarily with parents and other family members, but the school plays a central role for most children in StageIV (industry versus inferiority) and Stage-V (identity versus role confusion)(Miller, 1993).Schooling at different levels, classroom interactions, readings, and other school events play increasingly an important role in students' prosocial attitudes to be caring, sharing, cooperating and respecting others. Likewise Linn (2008) decoded social attitudes in six components; "concern for welfare of others, respect for laws, respect for property of others, sensitivity to social issues, concern for social institutions and desire to work toward social improvement".

Having drawn on the above discussion, summarily the youth interact at two levels; family and society. The factors involved at the familial level are the parents, related and unrelated peers and adults, the way they feel, speak and interact with the young ones. During formal schooling, 
modeling of the prosocial behaviors on the part of teachers and peers, their planned and unplanned school activities like coaching, guidance, and counseling etc., develop their social attitudes. At both levels, parental as well as instructional, undesired attitudes are curbed through disliking, negative reinforcement and reprimanding etc., while the prosocial behaviors are demonstrated, reinforced and promoted. In the following figure-1, the factors related to the development of social attitudes, the common desired social attitudes and antisocial behaviors are presented, to illustrate their interdependence as antecedents and consequents.

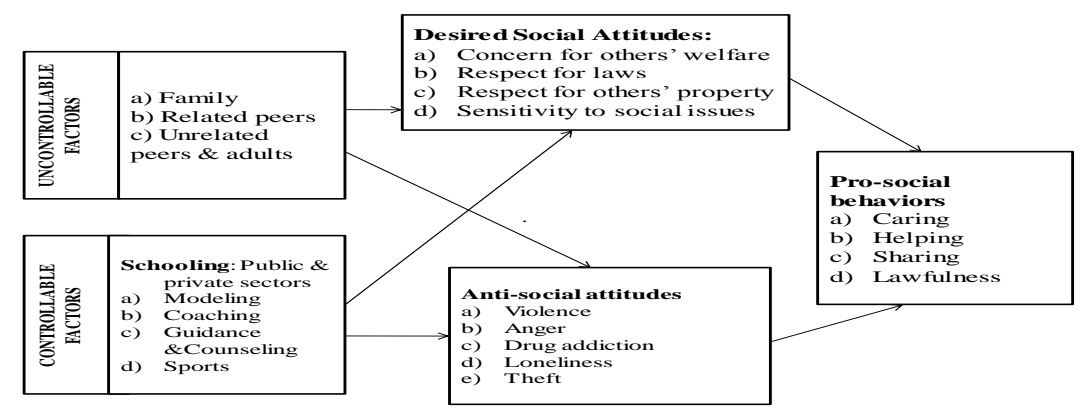

Figure 1: Theoretical framework of the study

In light of the given theoretical framework, public sector formal schooling in general and private sector in particular at different levels, receives criticism for not playing its effective role in developing students' prosocial attitudes and behaviors. Hence, the purpose of the current study is to clarify and establish the role of formal schooling, through assessing impact of overall schooling as well as schooling of public and private sectors in developing students' social attitudes to get empirical evidence for policy implications. Following research questions were formulated to be answered for meeting the purpose the study.

1. Does schooling at the different levels, contribute significantly in developing students' social attitudes?

2. Do the schools of public and private sectors; have equally significant impact on the development of students' social attitudes at different grade levels?

\section{Literature Review}

An extended review was done and related material is presented on the role of informal education and formal schooling regarding young 
children's different social attitudes, their social development and assessment of prosocial behaviors.

At the initial developmental stages, children develop physically, and alongside they develop their cognitive abilities as well as they do acquisition of language. According to Erikson, their social development happens in the beginning at, 'initiative versus guilt stage'. Among the influencing factors, peer relationships help them to come out of egocentric thinking and to start developing prosocial behaviors. As children improve their cognitive skills, they are also developing selfconcepts, ways of interacting with others, and attitudes toward the world (Slavin, 2006).

Having close connection with familial phase of coaching and informal education, children's preschool education gets start which is as readiness training. Students at the phase of pre-schooling learn skills that are supposed to prepare them for formal instruction later, such as how to follow directions, stick to a task, cooperate with others, and display good manners. Children are also encouraged to grow emotionally and develop a positive self-concept. The early primary grades are generally spent developing through Erikson's (1963) fourth stage of social development, industry versus inferiority, supposing that they have developed trust during infancy, autonomy, and initiative up to the preschool years. At this stage children are grown up for independent actions, cooperation with others and behaving in socially acceptable ways (McHale et al., 2003).

By the time children enter elementary schooling, they have developed skills like more complex thought, action, and social influence. At the given stage, according to Ruble, Eisenberg, and Higgins (1994), children use social comparisons to learn social norms to judge the social acceptance of their conduct. The middle school years also, often bring changes in the relationship between children and their teachers because at primary school, children easily accept and depend on teachers. During the upper elementary years, this relationship becomes more complex like sharing personal information, choosing teachers as role models (Roeser, Eccles, \& Samer off, 2000), or on the other hand to become alienated and consequently leading to delinquency and dropout (Murdock, 1999).

During schooling, the peer group takes on added importance for the cognitive and socio-emotional development of the students. Similarly, Inelmen (2011) proved that the various teaching-learning processes at schools play significant role in young ones grooming and are critical components of students' social development. By the sixth grade generally, students compare themselves with others, they make peer 
groups and learn from each other about their different worlds. They prefer gathering with teachers and peers instead of being alone (Durlak, Weissberg, Dymnicki, Taylor, \& Schellinger, 2011) and learn through, sharing of attitudes and values on how to prefer and to develop their own attitudes and values.

Contrary to the given research underpinnings, Bachtiar, Zubaidah, Corebima, and Indriwati (2018) argues that teaching models at schools are usually least focusing on students' social development. It means that students are rarely socially engaged beyond the family settings; very few of them are the members of any co-curricular group or society. Most of them have no access to any means of entertainment even most did not have access to libraries (UNDP, Pakistan National Human Development Report, 2017). The essential consequences of such failures during schooling can be observed through students' underdeveloped personalities, avoiding doing work, cheating in assessment tasks, noncooperative behaviors, negative social attitudes, absence of respect for others and their beliefs as well as inactiveness and lethargic attitudes toward welfare of others and social work.

A research report on students' civic attitudes and behaviors, was not much promising, which assessed only one year after of the education of high schools, where 29\%-45\% students showed presence of social competencies such as empathy, decision making, and conflict resolution skills and 29\% indicated about the provision of caring, encouraging environment from the school (Benson, 2006). Moreover, approximately $30 \%$ of high school learners were engaged in multiple high-risk behaviors, e.g., sex, violence, etc., which surely affect their school performance (Eaton et al., 2008).The suggested solution of such undesired social behaviors to Ngai, Cheung \& Li (2001) is that effectiveness of education increases when students are given the opportunity to participate in both school and community affairs, and schools should view themselves as an important microcosm for students to understand important social issues and practice concepts related to citizenship.

Urgency emerges from the stated dismal picture of the schooling towards prosocial behaviors, therefore the following types of social attitudes and prosocial behaviors need to be apprehended and ensured by pervasive instructional activities among the students during their formal schooling particularly from elementary to onwards.

Before going to elaborate the different types of attitudes, the concept of attitudes is defined with reference to the contemporary study that, 'a psychological tendency expressed by evaluating a particular entity with some degree of favor or disfavor (Wood, 2000). While Gelisli (2015) 
added that attitudes are one of the most important determinants of human behaviors. The researcher broadened this definition for the current research to social and civic attitudes that refer to individually held beliefs, evaluations, and judgments about diverse issues, events, and groups as they relate to their social and civic behaviors. Attitudes are relatively stable, but they can also fluctuate as a result of the changing social context and/or in the result of personal individual experiences, which are considered important and vital for social learning and prosocial behaviors.

There are three dimensions of one's attitude i.e. positive, negative and neutral. The positive dimension of attitude contains positive thoughts and feelings for an attitude towards someone, something or some issue. Similarly, Ulug, Ozden, and Eryilmaz (2011) defined prosocial attitude as being compassionate, perceptive, and supportive to others. Whereas, to Olweus (1994) and White and Kistner (1992),negative attitudes comprise of feelings of disliking, hate, anger, proud of an individual towards any event, person or issue. Additionally, Zanna and Rempel (1988), and Ulug et al., (2011) reported favoritism, annoyance, helplessness, intolerance and inconsistency as negative attitudes of teachers. Moreover, neutral attitude is having no definite feelings of liking and disliking towards something.

Prosocial attitudes are inevitable to keep society peaceful, caring, and supportive, as Mangal (2007) pointed out that developed social attitudes are significant for social adjustment and to become a wellreputed member of the society. Moreover, Ormston, Curtice, McConville, and Reid (2011) predicted that people having positive social attitudes, plays better role in maintaining social peace and harmony. Similarly, Roberts and Indermaur (2007) suggested that societies with people having positive attitudes would be more peaceful as compared to those with negative social attitudes. Further, Ahmad, Dureja, and Singh (2011) founded municipalities having people with high social attitudes have more economic progress as compared to those with underdeveloped social attitudes. Hence, social attitudes are crucial for personal development, social adjustment, and economic growth of the masses.

Conclusively the study focuses on Linn's (2008) six components of social attitudes, 'concern for others' welfare', 'respect for laws', 'respect for property of others', 'sensitivity to social issues', 'concern for social institutions', 'desire to work toward social improvement'. But, the researchers, in the light of Erikson theory as mentioned above, delimited the study to first four components due to approximate age level of students' social attitude development during elementary to their high level of schooling. 
The given components are further comprehended in the light of different studies like, Spicker (2013) elaborated that 'welfare for others' means serving to fulfill the needs of a needy person, while Bradshaw (1972) added two types of needs, i.e., felt and expressed needs. At the stage of moral development related to lawfulness and social obedience, an individual considers both necessary for social peace and justice, while having violation of law by an individual is ethically wrong according to Kohlberg (1973).Blake and Harris (2011) stated that property rights involve the decision rights relating to assets, which provides rights to owners to take certain actions using the property (rights of access), to prevent others from taking certain actions about the property (rights of exclusion), and to get benefit from the property.

\section{Methodology}

The study was causal-comparative and survey method by crosssectional design was followed, having suitability as recommended by Gay, Mills, \& Airasian, (2009) for assessing attitudes. Formal schooling, both in public and private sector, as a contributing factor to students' social attitudes, was fixed in the study to be investigated at three levels, i.e., grade 6,8 and 10 .

Population of the study was all the students from 6 to $10^{\text {th }}$ grade studying in public and private high schools of district Gujrat, Punjab, Pakistan. The students of the given grades were selected because according to Piaget(1952), being in age bracket of 12-18years, they develop their interests in social issues while Erikson (1980)described that during the same stage, individuals redefine their physiological identity and develop their pro or antisocial behaviors, particularly through social engagement.

The total 256 schools (141 public and 115 private) were population of the study. Sample size was 480 students i.e. 240 from each sector, which is sufficient according to Gay et al., (2009) that sample size 400 to 500 is adequate for survey research if a population is 5000 or more. Sample was selected through two-stage stratified random sampling. At the first stage, 8 schools each from the public and private sectors were selected randomly, while at the second stage, 10 students each from grades 6,8 and 10 were randomly selected from the each one of the selected schools. 


\section{Instrumentation}

A questionnaire was developed containing 26 items based on four components of social attitude as Linn (2008) held 'traditional written tests' inappropriate to assess social attitudes. The questionnaire was constructed in Urdu language for the fuller understanding of the questionnaire statements having pro or antisocial feelings, beliefs and perceptions. The statements for four sub-scales were embedded in social context of young children being assessed on their prevailing dimensions of social attitudes. There are 7, 6, 5 and 8 items of the sub-scales for measuring i) concern for others' welfare, ii) respect for laws, iii) respect for others' property and iv) sensitivity to social issues respectively. Three-point Likert scale was used to make the options easy to respond meaningfully, aligning the response levels to the three attitudinal dimensions, i.e., positive, neutral and negative. The questionnaire was validated on the basis of opinions of 14 experts including $3 \mathrm{PhDs}, 4 \mathrm{PhD}$ scholars, 6 MPhils and one MA in Education). Lawshe's (1975) rating criteria and formula was observed for the content validity index, which remained 0.86 . On the piloted data from fifty 6th graders, certain revisions, especially to simplify statements, were made in the instrument, and the resultant calculated Cronbach alpha was 0.71 i.e. acceptable according to Cohen, Manion \& Morrison (2007).

\section{Data Analysis}

The collected data from the sampled schools was analyzed first to assess the overall role of schooling. The results of ANOVA are presented in the following table 1. Further the results of Post hoc tests on two factors having significant F-ratio are presented in table 2, to find the level wise role of schooling.

Table 1

Analysis of variance of students' social Attitudes at three different levels of schooling

\begin{tabular}{|c|c|c|c|c|c|c|c|c|}
\hline \multirow{2}{*}{$\begin{array}{l}\text { Components of Social } \\
\text { Attitude }\end{array}$} & \multicolumn{2}{|c|}{$6^{\text {th }}$ Graders } & \multicolumn{2}{|c|}{$8^{\text {th }}$ Graders } & \multicolumn{2}{|c|}{$10^{\text {th }}$ Graders } & \multirow[b]{2}{*}{$\mathrm{F}$} & \multirow[b]{2}{*}{ Sig. } \\
\hline & Mean & SD & Mean & SD & Mean & SD & & \\
\hline $\begin{array}{l}\text { Concern for Others' } \\
\text { Welfare }\end{array}$ & 16.73 & 2.2 & 17.98 & 2.3 & 18.17 & 2.5 & 8.8 & $.001 * *$ \\
\hline Respect for Laws & 15.58 & 2.5 & 16.03 & 2.3 & 16.07 & 2.7 & 1.9 & .15 \\
\hline $\begin{array}{l}\text { Respect for others' } \\
\text { Property }\end{array}$ & 14.36 & 1.1 & 14.83 & 1.3 & 14.61 & 1.0 & 7.5 & $.001 * *$ \\
\hline Sensitivity to Social Issues & 18.17 & 2.5 & 19.04 & 1.9 & 18.96 & 2.1 & 1.3 & .28 \\
\hline
\end{tabular}


Table1presents analysis of variance (one way) used for mean scores difference among three groups. F-ratio is significant $(p<.05)$ hence difference found on concerns for others' welfare and respect for others' property among students' social attitudes at 6,8 and $10^{\text {th }}$ grade levels. However, insignificant difference ( $p>.05$ ) found at different levels of schooling on respect for laws and sensitivity to social issues. Results revealed that concerns for others' welfare and respect for others' property are developed significantly, across junior elementary, senior elementary and secondary levels of schooling, i.e., grade 6, 8, and 10 respectively, as compared to the insignificant development of respect for laws and sensitivity to social issues at schools.

In the following table post hoc analysis of those two factors, of which F-ratio was significant, is presented.

Table 2

POST HOC analysis on Social Attitudes

\begin{tabular}{lllllll}
\hline Components & \multicolumn{3}{l}{ Concerns for Others' } & Welfare & \multicolumn{3}{c}{ Respect for others' Property } \\
$\begin{array}{l}\text { During } \\
\text { Grades/levels }\end{array}$ & $6-8$ & $6-10$ & $8-10$ & $6-8$ & $6-10$ & $8-10$ \\
Mean Difference & -1.25 & -1.44 & -0.19 & -0.47 & -0.26 & 0.21 \\
Significance & $.001^{* *}$ & $.001^{* *}$ & .86 & $.001 * *$ & .08 & .19 \\
\hline
\end{tabular}

Degree of freedom $=478$

Table 2presents that both the components of social attitudes, i.e., concerns for others' welfare and respect for others' property are significantly developed $(\mathrm{p}<.05)$ among learners from 6 to $8^{\text {th }}$ grade, i.e. at elementary level. Similarly, the development of concerns for others' welfare continues to be significant $(\mathrm{p}<.05)$ during the period from grade 6 to 10 .However, results on concerns for others' welfare and respect for others' property during the period from grade 8 to $10^{\text {th }}$ showed insignificant ( $p>.05$ ) development. Further, the results show that even the schooling during the period from 6to $10^{\text {th }}$ grade showed insignificant (p>.05) impact on students' attitudes regarding respect for others' property.

There is debate that the quality of private sector schooling is better or of the public sector. Some of the studies like ASERs (2017 \& 2018) showed that the students of private sector schools are better in their performance on literacy ad numeracy skills. A critical question emerged that as whether the impact of given sectors' schooling differs on students' social attitudes development as well. Hence the following graphical comparison is presented to explain the phenomenon of social attitudes development at public and private schools. 


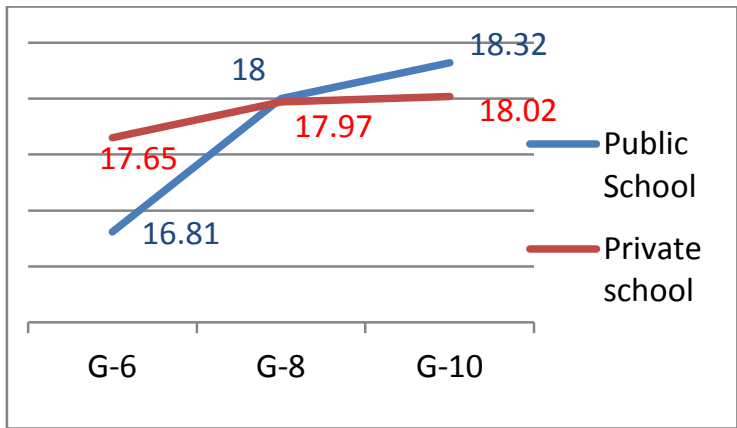

a) Concern for others' welfare

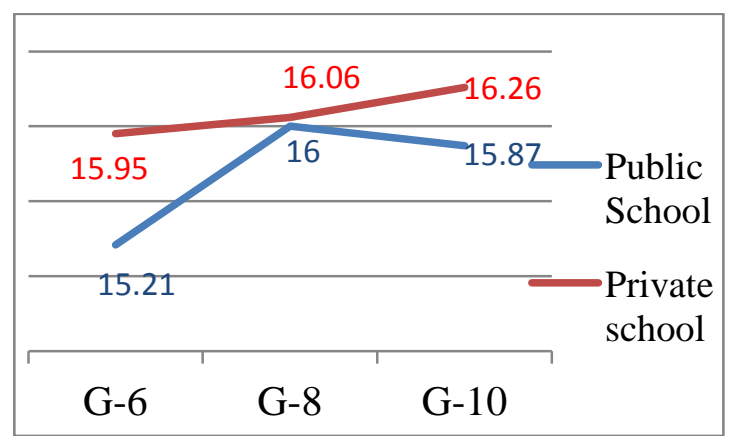

b) Respect for laws

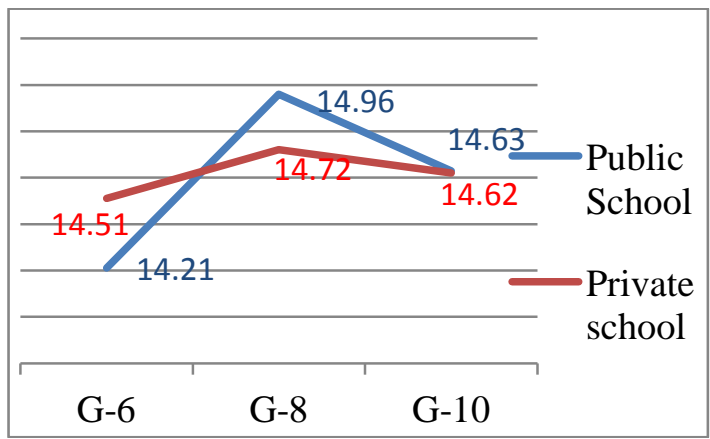

c) Respect for others' property 


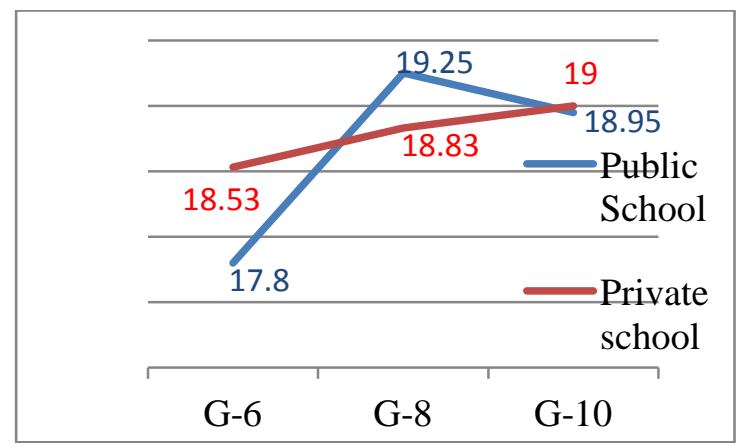

d) Sensitivity to social issues

Figure 2: Comparison of 4 components of social attitudes at public and private schools.

Results in figure 2 of all the four graphs show more increase in the development of students' social attitudes during the period from grade 6 to 8 at public schools as compared to private schooling. Further the slight downward trends showed during elementary to secondary in graphs b, c and $d$ are critical for their implications on the three components of social attitudes. However, the graph $\mathrm{a}, \mathrm{b}$ and $\mathrm{d}$ reflect somehow unnoticeable growth of students social attitudes at private sector schooling during the period from grade 6 to 10 .

In the light of graphic representation of data, sector wise results of the further sophisticated analysis are presented in the following.

Table 3

Analysis of variance of Public Sector Students' Social Attitudes at three levels

\begin{tabular}{|c|c|c|c|c|c|c|c|c|c|}
\hline \multirow{2}{*}{$\begin{array}{l}\text { Components of } \\
\text { Attitude }\end{array}$} & \multirow[t]{2}{*}{ Social } & \multicolumn{2}{|c|}{$6^{\text {th }}$ Graders } & \multicolumn{2}{|c|}{$8^{\text {th }}$ Graders } & \multicolumn{2}{|c|}{$10^{\text {th }}$ Graders } & \multirow[b]{2}{*}{$\mathrm{F}$} & \multirow[b]{2}{*}{ Sig. } \\
\hline & & Mean & SD & Mean & SD & Mean & SD & & \\
\hline $\begin{array}{l}\text { Concerns for } \\
\text { welfare }\end{array}$ & others' & 16.81 & 2.5 & 18.00 & 2.3 & 18.32 & 1.9 & 9.44 & $.001 * *$ \\
\hline Respect for laws & & 15.21 & 2.2 & 16.00 & 1.8 & 15.87 & 1.9 & 3.54 & $.031 *$ \\
\hline $\begin{array}{l}\text { Respect } \\
\text { property }\end{array}$ & others' & 14.21 & 2.0 & 14.96 & 1.2 & 14.63 & 1.9 & 3.63 & $.033 *$ \\
\hline Sensitivity to socia & issues & 17.80 & 2.7 & 19.25 & 2.2 & 18.95 & 2.3 & 8.01 & $.001 * *$ \\
\hline
\end{tabular}

Table 3 presents results of one way ANOVA on means of three groups i.e., 6,8 and $10^{\text {th }}$ graders on four components of social attitude. 
The significant F-ratios $(\mathrm{p}<.05)$ show that across the three levels, public sector schooling contributes in students' social attitudes development, i.e., on all of their four attitudinal components.

Having significant F-ratio, further results of POST HOC test are presented in the following tables, to observe the level wise impact of public sector schooling.

Table 4

POST HOC on Public Sector Students' Social Attitudes Development

\begin{tabular}{|c|c|c|c|c|c|c|c|c|c|}
\hline \multirow{3}{*}{ 离 } & Grades & $6-8$ & $6-10$ & $8-10$ & \multirow{3}{*}{$\begin{array}{l}\frac{\overrightarrow{0}}{0} \\
\frac{0}{0} \\
\frac{0}{2}\end{array}$} & Grades & $6-8$ & $6-10$ & $8-10$ \\
\hline & Mean & -1.18 & -1.51 & -0.33 & & Mean & -0.79 & -0.66 & 0.13 \\
\hline & $\begin{array}{l}\text { Diff. } \\
\text { Sig. }\end{array}$ & & & & & $\begin{array}{l}\text { Diff. } \\
\text { Sio. }\end{array}$ & & & \\
\hline \multirow{3}{*}{ 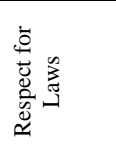 } & Grades & $6-8$ & $6-10$ & $8-10$ & \multirow{3}{*}{ 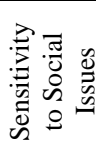 } & Grades & $6-8$ & $6-10$ & $8-10$ \\
\hline & Mean & -0.75 & -0.42 & 0.33 & & Mean & -1.45 & -1.15 & 0.30 \\
\hline & Sig. & $.02 *$ & .34 & .57 & & Sig. & $.001 * *$ & $.001^{* *}$ & .82 \\
\hline
\end{tabular}

Degree of freedom $=238$

Table 4 illustrates that the four components of social attitudes are significantly developed $(p<.05)$ among learners during the periodfrom6 to $8^{\text {th }}$ grade but insignificantly developed ( $\left.p>.05\right)$ from 8 to $10^{\text {th }}$ grade. However, concerns for others' welfare and sensitivity to social issues also show significant development from 6 to $10^{\text {th }}$ grade but respect for laws and respect for others' property showed insignificant development in this regard.

Table 5

Analysis of variance of Private Sector Students' Social Attitudes at three levels

\begin{tabular}{|c|c|c|c|c|c|c|c|c|}
\hline \multirow{2}{*}{$\begin{array}{l}\text { Components of Social } \\
\text { Attitude }\end{array}$} & \multicolumn{2}{|c|}{$6^{\text {th }}$ Graders } & \multicolumn{2}{|c|}{$8^{\text {th }}$ Graders } & \multicolumn{2}{|c|}{$10^{\text {th }}$ Graders } & \multirow[b]{2}{*}{$\mathrm{F}$} & \multirow[b]{2}{*}{ Sig. } \\
\hline & Mean & SD & Mean & SD & Mean & SD & & \\
\hline $\begin{array}{l}\text { Concerns for others' } \\
\text { welfare }\end{array}$ & 17.65 & 2.23 & 17.97 & 2.25 & 18.02 & 2.42 & 0.62 & .54 \\
\hline Respect for laws & 15.95 & 2.26 & 16.06 & 1.94 & 16.26 & 1.91 & 0.48 & .62 \\
\hline $\begin{array}{l}\text { Respect for others' } \\
\text { property }\end{array}$ & 14.51 & 2.37 & 14.72 & 1.79 & 14.62 & 2.59 & 0.34 & .72 \\
\hline Sensitivity to social issues & 18.53 & 2.37 & 18.83 & 1.78 & 19.00 & 2.59 & 0.85 & .43 \\
\hline
\end{tabular}

Table 5 depicts the results of ANOVA showing that there is no significant development $(\mathrm{p}<.05)$ of the four given components of social attitudes across the three levels, i.e., $6^{\text {th }}, 8^{\text {th }}$ and $10^{\text {th }}$ grades at private sector schools. The results revealed that there is least focus of private schooling on development of social attitudes among students. 


\section{Discussion}

The study explored the impact of schooling on students' social attitudes which leave lasting imprints on their thinking and behaviors. Results revealed that respect for others' welfare and respect for others' property are developed better as compared to respect for laws and sensitivity to social issues through schooling jointly from 6 to $8^{\text {th }}$ grade. However, schooling from $8^{\text {th }}$ to $10^{\text {th }}$ grade found ineffective regarding development of the four significant components of social attitudes among learners. The reason might be the majority of learners probably who do not reflect pro-social behaviors but focus on getting good grades through memorizing or any means even unfair (Mahmood \& Gondal, 2017).Likewise, Bachtiar et al. (2018) reported that teaching models used by teachers focus least on the social development of learners and its consequences can be observed through students' irresponsibility in doing homework, cheating in assignments, and lack of observance of institutional and social laws.

Results are evident that public sector schooling, where mostly the lower class children were studying, is performing better from 6 to $8^{\text {th }}$ grade as compared to private sector. Similarly, many researchers (e.g. Karweit, 1994; Sachs, 2000) reported that many experiences provided at schools are more critical for lower class children than for middle class children. The better results of schooling from 6 to $8^{\text {th }}$ grade than from grade 8 to 10 may be due to natural schooling environment that doesn't include centralized examination system which creates pressures on teachers, management and students to have good scores in departmental tests to avoid reprimand and punishments from the government. In general, schooling provides environment to students where they can interact with other students and develop socially as McHale et al., (2003) explains that during the elementary school years, friends are the sources and models of social, emotional and cognitive learning for each other. This is the age stage when teenagers develop attitudes towards schooling, neighborhood and society. Attitudes do not need blackboards, or multimedia etc., to teach but attitudes or behaviors are developed from behaviors.

The findings related to 6 to $8^{\text {th }}$ graders' attitudes are in accordance with the Inelmen (2011) study that schooling plays a significant role in the social development of learners but the findings from 8 to $10^{\text {th }}$ grade are not much promising accordingly. Moreover, results are evident that private schooling is ineffective at the three levels to develop social attitudes among learners although their students are even somewhat better at their initial stage of elementary education in their social 
attitudes as compared to the students of public sector. Itimplies the competitive environment of obtaining high scores and teachers' ineffectiveness, being untrained and having lack of commitment, for modeling prosocial attitudes and behaviors.

Mahmood and Gondal (2017) reported that the focus of learners remained to obtain more scores through the memorization of textbook content. In such conditions where the young ones have not socially developed attitudes, how one can expect of them to be socially cohesive (Slavin, 2006)? The results about the private schooling and particularly in public sector as well, implied that school system teaches students to do well in examinations, but it does not teach them to engage with the material they read. What they generally know, cannot internalize to make meanings of the world they live in. What is the point of teaching and learning if the students are not going to change the way they feel and look around their society and world?

\section{Conclusions \& Recommendations}

The results of the study revealed the status of prosocial attitudes of the students across junior to senior elementary and secondary schooling (during the period of grade 6 to 8 and then to grade 10), which reflect that secondary schooling in both sectors while elementary in private schools, have negligible impact on students' social attitudes. Although the given period of schooling during formative phases is critical for social lives. The youth having developed social attitudes may tend to voluntary actions, which are socially desired for others such as caring, sharing, and cooperating, etc. On the basis of study results along with the finding of other research studies (Berrueta-Clement, Schweinhart, Barnett, Epstein, \& Weikart, 1984; Eisenberg \& Mussen, 1989; Hoffman, 1993; Schweinhart, Barnes, \& Weilzart, 1993), following conclusions with related recommendations for policy purpose are presented to ensure the effective development of student's social attitudes and consequently prosocial behaviors.

a) Assessment procedures at schools need to be more inclusive of all the aspects of students' development like socio-emotional and moral ones, because what we test that we get.

b) The results are obvious that there is need to develop more awareness of laws, and social issues among the students particularly at secondary level, which is supposed to be the promoter of social development. It implies that teachers are more focused on academic during class teaching but unfortunately at the cost of critical social aspects essential for a harmonious and peaceful society. 
c) The graphical results showed that students' social attitudes at elementary level were better in public schools as compared to private ones, furthermore, the slight downward trends from elementary to secondary overall schooling is alarming. It implies that the instructional approaches need a significant shift from academic to total development of the students.

d) The ANOVA and Post hoc results presented a crucial picture of private schooling where no significant increase was found in students' social attitudes, which implies that the schooling is exclusively focus on content teaching and students mental and social horizons are unaddressed to be broadened. For this parenting session and teachers professional trainings are needed to be on the same page for students' comprehensive training and education. The familial set up needs to allow the children to have contacts with those adults who indicate concerns for others and aspire children that aggressive attitudes and behaviors are unacceptable. Further they who, when interact with children, attributes positive characteristics to children when they do well (Grusec \& Goodnow, 1994).

e) During teaching, class discussion on the pro and anti-social behaviours particularly with reference of their personal and social consequences, as well as reinforcement techniques are described to be more helpful for cultivating prosocial behaviors among learners because they push learners from negative to positive thinking, refined beliefs and consequently socially desired actions. 


\section{References}

Ahmad, H., Dureja, G., \& Singh, S. (2011). Social attitude and socio economic status of physical education students of Jammu Kashmir and Punjab states. International Journal of Sociology and Anthropology, 3(11), 436.

Bachtiar, S., Zubaidah, S., Corebima, A. D., \& Indriwati, S. E. (2018). The spiritual and social attitudes of students towards integrated problem based learning models. Issues in Educational Research, 28(2), 254-270.

Benson, P. L. (2006). All kids are our kids: What communities must do to raise caring and responsible children and adolescents.(2nd ed.). San Francisco. CA: Jossey-Bass.

Berrueta-Clement, J. R., Schweinhart, L., Barnett, W, Epstein, A. S., \& Weikart, D., (1984). Changed lives: The effects of the Perry Preschool Program on youths through age 19. Monographs of the High/Scope Educational Research Foundation, (8).

Blake, P. R., \& Harris, P. L. (2011). Early representations of ownership. New directions for child and adolescent development, 2011(132), 39-51.

Blum, R. W., Libbey, H. P., Bishop, J. H., \& Bishop, M. (2004). School connectednessstrengthening health and education outcomes for teenagers. Journal of School Health, 74(7), 231-235.

Bradshaw, J. (1972). Taxonomy of social need. In McLachlan, Gordon, (ed.) Problems and progress in medical care: essays on current research, 7th series. Oxford University Press, London , 71-82.

Can, G. (2011). Kişilik gelişimi (Development of personality). B. Yesilyaprak (Ed.) (2011). Egitim psikolojisi: Gelisim-ogrenmeogretim (Educational psychology: Development-learning-teaching) ( $7^{\text {th }}$ ed.). Ankara: Pegem Akademi.

Cohen, L., Manion, L. \& Morrison, K. (2007). Research Methods in Education ( $6^{\text {th }}$ ed.). New York: Routledge.

Durlak, J. A., Weissberg, R. P., Dymnicki, A. B., Taylor, R. D., \& Schellinger, K. B. (2011). The impact of enhancing students' social and emotional learning: A meta-analysis of school-based universal interventions. Child Development, 82(1), 405-432. 
Eaton, D. K., Kann, L., Kinchen, S., Shanklin, S., Ross, J., Hawkins, J.,... \& Lim, C. (2008). Youth risk behavior surveillance--United States, 2007. Morbidity and mortality weekly report. Surveillance summaries (Washington, DC: 2002), 57(4), 1-131.

Eisenberg, N., \& Mussen, P. H. (1989). The roots of prosocial behavior in children. Cambridge University Press.

Erikson, E. H. (1963). Childhood and society (2nd ed.). New York: Norton.

Erikson, E. H. (1980). Identity and the life cycle (2nd ed.). New York: Norton.

Gay, L. R., Mills, G. E., \& Airasian, P. W. (2009). Educational Research: Competencies for Analysis and Applications, Student Value Edition. Upper Saddle River, NJ: Merrill.

Gelisli, Y. (2015). Development of "educational faculty students' attitudes towards their departments" attitude scale study. ProcediaSocial and Behavioral Sciences, 174, 31373143.

Grusec, J. E., \& Goodnow, J. J. (1994). Impact of parental discipline methods on the child's internalization of values: A reconceptualization of current points of view. Developmental Psychology, 30(1), 4.

Hoffman, M. L. (1983). Affective and cognitive processes in moral internalization. Social cognition and social development: A Sociocultural Perspective, 236-274.

Inelmen, E. (2011). Integrating all learning activities around a city study curriculum. Cypriot Journal of Educational Sciences, 6(1), 37-45.

Iram, S., \& Ambreen, M. (2017). Psycho-Social Learning Environment in Elementary Classrooms and its Relationship with Students'academic Achievement. Pakistan Journal of Education, 32(1).

Karweit, N. L. (1994). Issues in kindergarten organization and curriculum. Preventing early school failure, 78-101.

Kohlberg, L. (1973). The claim to moral adequacy of a highest stage of moral judgment. The journal of philosophy, 70(18), 630-646.

Lawshe, C. H. (1975). A quantitative approach to content validity. Personnel Psychology, 28(4), 563-575. 
Linn, R. L. \& Miller, M.D. (2008). Measurement and assessment in teaching $\left(9^{\text {th }}\right.$ ed.). New Delhi, India: Pearson Education.

Mahmood, T., \& Gondal, M. B. (2017). Effect of school environment on students' achievement: cross comparison of Urdu and English medium classes in Punjab province. Pakistan Journal of Education, 34(1), 67-80.

Mangal, S. K. (2007). Essentials of educational psychology. PHI Learning Pvt. Ltd.

McHale, S. M., Dariotis, J. IZ., \& IZauh, T. J. (2003). Social development and social relationships in middle childhood. In R. M. Lerner, M. A. Easterbroolzs, \& J. Mistry (Eds.), Handbook of psychology: Vol. 6. Developmental psychology (pp. 241-265). Hobolten, N J: Wiley.

Miller, P. H. (1993). Theories of developmental psychology ( $3^{\text {rd }}$ ed.). New York: Freeman.

Murdock, T. B. (1999). The social context of risk: Status and motivational predictors of alienation in middle school. Journal of Educational Psychology, 91 (1), 62-75.

Najam, A., Bari, F, and Ahmad, S. (2017). Pakistan National Human Development Report: United Nations Development Programme, Islamabad, Pakistan.

Ngai, N. P., Cheung, C. K., \& Li, C. K. (2001). China's youth policy formulation and youth participation. Children and Youth Services Review, 23(8), 651-669.

Olweus, D. (1994). Bullying at school: Basic facts and effects of a school-based intervention program. Journal of Child Psychology and Psychiatry, 35(1), 171-190.

Ormston, R., Curtice, J, McConville, S. \& Reid, S. (2011). Scottish social attitudes survey 2010 attitudes to discrimination and positive action. Scotland: Queens Printers.

Piaget J. (1952). The Origins of Intelligence in Children. New York: International Universities Press.

Roberts, L., \& Indermaur, D. (2009). What Australians think about crime and justice: Results from the 2007 Survey of Social Attitudes. Canberra: Australian Institute of Criminology. 
Roeser, R., Eccles, J., \& Sameroff, A. (2000). School as a context of early adolescents' academic and social-emotional development: A summary of research findings. The Elementary School Journal, $100(5), 443-472$.

Ruble, D. N., Eisenberg, R., \& Higgins, E. T. (1994). Developmental changes in achievement evaluation: Motivational implications of self- other differences. Child Development, 65(4), 1095-1110.

Sachs, J. (2000). The activist professional. Journal of educational change, 1(1), 77-94.

Schweinhart, L. J., Barnes, H. V., Weikart, D. P., Barnett, W., \& Epstein, A. (1993). Significant benefits: the High. Scope Perry Preschool study through age, 27, 55.

Schwille, J. \& Amadeo J. (2002). The paradoxical situation of civic education in schools: Ubiquitous and yet elusive. New Paradigms and Recurring Paradoxes in Education for Citizenship, 5, 105-136

Slavin, R. E. (2006). Educational psychology: theory and practice. Boston: Pearson Education.

Spicker, P. (1988). Principles of Social Welfare: An Introduction to thinking about the welfare state ( $1^{\text {st }} \mathrm{ed}$.). London: Routledge.

Ulug, M., Ozden, M. S., \& Eryilmaz, A. (2011). The effects of teachers' attitudes on students' personality and performance. Procedia-Social and Behavioral Sciences, 30, 738-742.

White, K. J., \& Kistner, J. (1992). The influence of teacher feedback on young children's peer preferences and perceptions. Developmental Psychology, 28(5), 933.

Wood, W. (2000). Attitude change: Persuasion and social influence. Annual Review of Psychology, 51(1), 539-570.

Zanna, M. P., \& Rempel, J. K. (2008). Attitudes: A new look at an old concept. In R. H. Fazio \& R. E. Petty (Eds.), Key readings in social psychology. Attitudes: Their structure, function, and consequences (p. 7-15). Psychology Press.

\section{Citation of this Article:}

Arshad, S., \& Zaman, S. (2020). Impact of different levels of schooling on development of students' social attitudes. Pakistan Journal of Education, 37 (1), 75-94. 